\title{
«КЛЮНІЙСЬКЕ ПРАВО» ЯК ГОЛОВНИЙ ЧИННИК ПАПСЬКОЇ РЕФОРМАЦІЇ КАТОЛИЦЬКОЇ ЦЕРКВИ В ДОБУ СЕРЕДНЬОВІЧЧЯ
}

Забзалюк Д. $\epsilon$.

Стаття присвячена сутності та змісту реформації в Католицькій церкві, яка була започаткована духовними особами монастиря у Клюні в X-XI cmoлітmях. У статmі аналізується вплив клюнійських реформ на формування політико-правової доктрини Католицької церкви, а також на політичний, соціально-економічний, культурний, правовий та духовний розвиток Західної Європи загалом. У статmі вводиться в науковий обіг таке поняття, як «клюнійське право».

У статті вказується на те, що велика реформа клюнійських монахів була спрямована на підпорядкування життя всього духовенства чернечим порядкам. Із самого початку проведення цієї реформи було підтримане найбільш прогресивними князями та єпископами, а вже потім до їі реалізації підключилось i папство. Клюнійці прагнули створити сильну централізовану церковну організацію, тому сприяли звеличенню папської влади. Водночас і самі римські папи проводили централістську політику в Католицькій церкві. Звичайно, вони вступили в союз із клюнійчями, побачилии в них свою опору.

У статті акцентується увага на тому, що масштабність клюнійських реформ дає підстави говорити про вироблення специфічного клюнійського права, яке ґрунтувалось на синтезі черковних та канонічних норм, а також створювало умови для розвитку цивілізованих цивільно-правових відносин та міжнародного права. Саме клюнійське право лежало в основі цієї і наступних папських реформацій. Навіть незважаючи на те, що папські реформи не прийняли більшість європейських правителів і кліриків, клюнійські нововведення дозволили папству стати наймогутнішою державною організачію середньовічної Європи. Після Папської революції була створена нова система канонічного права, яка відділилась від богослужіння, риторики і моралі; у цій системі використовувались, з одного боку, знову відкрите римське право в аспекті мови і правової доктрини, з іншого - новий схоластичний метод під час зведення в єдине чіле суперечливих текстів

Ключові слова: «клюнійське право», Католицька церква, клюнійські реформи, Папа Римський, інвеститура, канонічне право.
Zabzaliuk D. Ye. "Cluny law" as main factor of the pope reform of the Catholic Church in the Middle Ages

The given article is dedicated to the essence and content of the reformation in the Catholic Church which was established by the spiritual persons of the monastery in Cluny in X-XI century. The impact of Cluny reforms upon the formation of the political and legal doctrine of the Catholic Church as well as political, socio-economic, cultural, legal and spiritual development of the Western Europe overall have been analyzed in the article. The concept "Cluny law" was first introduced in the work.

The article points out that the great reform of the Cluny monks was aimed at subordinating the lives of all the clergy to the monastic order. From the very beginning, this reform was supported by the most progressive princes and bishops, and only then did the papacy join in its implementation. The Cluny sought to create a strong centralized church organization and therefore contributed to the glorification of papal authority. At this time, the popes themselves pursued a centralist policy in the Catholic Church. Of course, they entered into an alliance with the Cluny, seeing in them their support.

The article emphasizes that the scale of Cluniac reforms gives grounds to talk about the development of specific Cluniac law, which was based on a synthesis of ecclesiastical and canonical norms, as well as created conditions for the development of civilized civil relations and international law. It was the Clunian law that formed the basis of this and subsequent papal reforms. Even though the papal reforms were not accepted by most European rulers and clergy, the Cluny innovations allowed the papacy to become the most powerful state organization in medieval Europe.

After the Papal Revolution, a new system of canon law was created, separated from worship, rhetoric, and morality; this system used, on the one hand, the rediscovered Roman law in terms of language and legal doctrine, and, on the other, a new scholastic method in bringing together contradictory texts.

Key words: "Cluny law", The Catholic Church, Cluny reforms, Pope, investitura, canonic law. 
Постановка проблеми та їі актуальність. Ще задовго до початку Хрестоносного руху на Схід Римська католицька церква стає головним виразником ідей та доктрин середньовічного суспільства i, спираючись на величезні земельні і грошові ресурси, посідає панівне місце в тодішньому феодальному суспільстві. Церква як провідний ідеологічний інститут, а також виразник політико-правової доктрини доби Середньовіччя здійснює комплекс заходів щодо посилення суспільної та політичної згуртованості, а також об'єднання середньовічного феодального світу, сміливо втілює план створення вселенської папської теократичної феодальної держави.

Заради досягнення цієї мети папство за допомогою низки заходів усіляко пристосовувалась до еволюційних процесів у середньовічному соціумі, а також забезпечувало його необхідними духовними гаслами. Це, зокрема, знайшло своє відображення у проведенні реформації Католицької церкви, яку розпочали ченці монастиря Клюні, суть якої полягала в підпорядкуванні всього світського духовенства чернецтву, а також у домінуванні над світською владою.

Аналіз останніх досліджень і публікацій. Проблемами реформації Західної католицької церкви цікавилися низка відомих дослідників, зокрема: М. Барбер, М. Бейджент, Дж.Г. Берман, П. Віймар, Н. Дейвіс, А. Демурже, Л. Джероза, Ф. Кардіні, В.Дж. Колінж, Л. Колмен, І. Конгар, Б. Куглєр, Е. Лавіс, Ж. Ле Гофф, Д. Легман, Р. Лей, Р. Лі, Г. Лінкольн, Дж.Г. Лінч, П. де Лоб'є, Р. МакБрейн, М. Мельвіль, Р. Мішо, Л. Мулен, Дж. Омен, І. Отт, Ж. Рішар, А. Рамбо, Д. Робінсон, Ж. Руа, К. Хілленбрандт та інші.

Щодо радянської історіографії, то вона, навпаки, не надто захоплювалась вивченням даної проблематики, оскільки питання релігії зазвичай замовчувались, ігнорувались або висвітлювались досить однобоко. Варто відзначити деякі наукові розвідки окремих істориків і правників: Д. Александрова, А. Андреєва, В. Гараджі, А. Доманіна, Є. Жарінова, С. Жаркова, М. Заборова, Л. Карсавіна, К. Каутського, П. Корявцева, В. Матузової, А. Назаренка, В. Пашуто, Р. Печнікової, $\epsilon$. Трубецького, Ф. Успенського, М. Шейнмана, А. Ястребицької та інших.

В українській історіографії також наявна суттєва прогалина в дослідженні цієї тематики. Навіть більше, дослідження в аспекті реформування Середньовічної церкви в добу раннього Середньовіччя практично відсутні. Однак усе ж варто відзначити наукові пошуки, які представлені у працях: О. Борисової, Р. Бутенко, О. Головко, В. Ідзьо, Т. Каляндрука, М. Котляра, Н. Крестовської, В. Лубського, Р. Лукінової, В. Макарчука, О. Масана, В. Мудревича, А. Федорука, Ю. Ячейкіна й інших.

Метою статті $\epsilon$ аналіз сутності клюнійських реформ X-XI ст., їхнього впливу на формування політико-правової доктрини Католицької церкви.

Виклад основного матеріалу. Економічно найбільш сильною церковною установою, могутнім провідником релігійної ідеології були монастирі. Саме вони ще в X ст. і взяли на себе почин цілої низки перетворень у Католицькій церкві, які повинні були укріпити ії моральні і матеріальні позиції, удосконалити організацію, підвищити авторитет. Ініціатором цих перетворень виступив бургундський монастир Клюні, заснований у 910 р., тому весь церковно-реформаторський рух дістав назву клюнійського. Монастир у Клюні став ініціатором тієї великої реформи, яка пробудила до життя Західну Європу в XI ст. [1, с. 230; 2, с. 69].

Велика реформа клюнійських монахів спрямовувалась на підпорядкування життя всього духовенства чернечому укладу. Розпочата ченцями із Клюні, реформа була спочатку підтримана найбільш прогресивною аристократією, а згодом і самим Папою.

Клюнійці вимагали дійсного повернення до апостольського життя та відродження первинного образу церкви. Було б неправильно розглядати ці прагнення чернецтва як бажання повернутись на ступінь грецької церкви і вийти за рамки західного католицизму: ні - ці монахи мали на увазі деяку позитивну програму: християнське життя всього християнства загалом [3, с. 150].

Монастир у Клюні з моменту його утворення завжди посідав особливе місце в суспільстві. Місцеві абати мали неабиякий вплив на релігійну та державну політику. До їхньої думки дослухалися не лише вищі церковні ієрархи, зокрема й Папа, але і наймогутніші представники світської влади. До святих були віднесені п'ять із дев'яти перших настоятелів Клюнійського абатства.

Клюнійці прагнули створити сильну централізовану церковну організацію, тому сприяли звеличенню папської влади. Водночас і самі римські папи проводили централізаторську політику в Католицькій церкві. Звичайно, вони вступили в союз із клюнійцями, побачили в них свою опору. Одним із важливих заходів для зміцнення папства було встановлення нового порядку виборів пап: за постановою Латеранського собору 1059 р., рим- 
ських первосвящеників мала вибирати колегія кардиналів. Ні імператори Священної римської імперії, ні інші світські феодали більше не могли втручатись у вибори [4, с. 18].

Свого фундаментального вираження дані реформи набули в політиці клюнійського ченця Гільдебрандта, який увійшов в історію під ім'ям Папи Римського Григорія VII.

Французьке прислів'я «усі дороги ведуть у Рим», можливо, ніколи не містило більш правильної характеристики стану Західної Європи, ніж у другій половині XI ст., у дні понтифікату Папи Григорія VII [5, с. 100], адже саме тоді відбувались надзвичайно складні та важливі для всього християнського світу події. Зокрема, на тлі християнізації Скандинавії та Русі відбувся розкол Церкви на Західну та Східну, що проявилось у появі схизматиків греків на Сході, тривали тотальні міжусобні війни феодалів у Франції та Німеччині [1, с. 231].

Варто зазначити, що Католицька церква виявилась готова до таких змін, що знайшло відображення у формуванні нової державно-правової доктрини, звичайно, не без участі клюнійців. Найбільш яскраво це виражалось у програмі так званої «папської теократії», тобто «встановлення верховної влади папи в церковних і світських справах» [6, с. 35], яку висунув у 1075 р. Папа Григорій VII і сформулював їі у своєму знаменитому “Dictatus Papae” («Диктат Папи»). «І в цю теократичну монархію, за його задумом, повинні були увійти всі християнські держави» [7, с. 32]. Крім того, «Папа Григорій VII та інші відомі богослови проповідували існування правового порядку не тільки всередині окремих держав, але і в міжнародній сфері» [5, с. 363].

Ідея теократичної монархї мала величезний глибинний зміст, оскільки вперше була висловлена теорія об'єднаної Європи на основі християнської віри, що мало позитивно вплинути на іiі політичний, соціально-економічний, культурний та духовний розвиток [1, с. 232; 2, с. 70].

У рамках такого політико-правового бачення Папа Римський, який оцінював складну ситуацію, у якій опинилась Західна Європа наприкінці XI ст. , а також спирався на свій колосальний авторитет, прагнув організувати й очолити рух європейців на Схід із метою звільнення від мусульман головної християнської святині - Єрусалиму. Це була перша спроба організації хрестового походу, «хоча думка про такий захід ще за сто років до нього була висловлена Папою Сильвестром II» [8, с. 3].
Варто зазначити, що «ідея хрестових походів чудово вписувалась у перспективу перетворення християнського світу, яке задумувалось впливовим клюнійським братством» [9, с. 150].

Логічним завершенням усього став церковний собор у Клермоні 1095 р., на якому Папа Урбан II, який і сам був вихідцем із монастиря у Клюні, висловив ідею організації Хрестоносного руху на Схід, чітко дав зрозуміти, що саме Папа, а не монархи, стоїть на чолі латинського світу і виражає ідею його об'єднання.

Звичайно, заклик, який виходив від вищого церковного ієрарха, зі зброєю в руках звільнити Гріб Господній, м'яко кажучи, не зовсім відповідав християнському віровченню. Адже завоювання одними народами інших за допомогою застосування насильства, навіть незважаючи на високу мету даної місії, однозначно, виходив за рамки Святого Писання. I ми вважаємо це безперечним фактом! Адже хрестоносці на шляху до Єрусалиму та й безпосередньо в ньому показали неприпустиму жорстокість, зокрема і щодо мирного населення. Навіть більше, досить цинізму було і в тому, що за участь у хрестовому поході вище католицьке духовенство і сам верховний понтифік обіцяли індульгенції для всіх його учасників. I такі думки мають абсолютне право на існування [1, с. 232].

Однак можна з упевненістю вважати, що окреслені процеси в добу раннього Середньовіччя мають набагато глибше підґрунтя, розглядати їх потрібно комплексно, а не однобоко, зокрема з урахуванням тих соціальних, політичних, економічних, культурних та правових реалій, які склалися наприкінці XI ст.

Можна по-різному ставитись до діяльності папства та його ролі в реформації Церкви, хрестоносному русі, намагання підпорядкувати світську владу церковній тощо. Однак, «які б не були помилки щодо виконання свого служіння, у яких звинувачують Пап, ми повинні засвідчити, що ніхто у світі не протестував проти цих помилок так постійно і так сильно, як самі ж Папи. Яким чином? По-різному, але більше всього постійними зусиллями підтримувати, поширювати і розвивати любов і служіння Христу» [10, с. 133].

Варто сказати, що Католицька церква дбала і про власний авторитет, адже сама була «заражена» тими гріхами феодального суспільства, проти яких вона боролася. Саме тому «Папа Григорій VII розпочав серйозні зміни всередині самої Церкви, як-от: боротьба проти симонії, зверхність церковної інвеститури над світською, целібат тощо» [11, с. 274]. 
Що стосується симонії, то Папа Григорій VII уважав іï найтяжчим злочином, адже коренем цього зла вважав той факт, що заміщення вищих церковних посад залежить здебільшого від світських володарів. Саме тому Папа Григорій VII розпочав знаменитий спір за інвеституру, яка полягала у просуванні ідеї зверхності папи у призначенні єпископів, священиків і абатів. Дані реформістські задуми папи підтримували відомі й авторитетні богослови, як-от Ансельм Лукський, Гебгард Зальцбурзький, Плацид Нонантульський та інші [1, с. 233].

І справді, можна констатувати той факт, що до кінця XI ст. папи не мали такої потужної влади, бо залежали від імператорів і монархів, які подекуди і призначали пап, угідних їм. «Була відсутня також і власна церковна ієрархія серед єпископів і священиків, яких призначав король або сеньйор. Єпископ Риму був лише першим серед рівних. Його згода була не обов'язкова для призначення інших єпископів та священиків, за канонічним правом він не міг скасувати ухвалені ними рішення" [12, с. 49].

Однак у процесі проведення Клюнійської реформації ситуація суттєво змінилась на користь папства. Католицька церква стала наймогутнішою організацією в Європі, яка визначала практично всю зовнішню політику європейських держав, їхній політичний, економічний, культурний, правовий та духовний розвиток. «Монастирі були центрами науки, медицини й освіти. Правителі створювали привабливі умови для монастирів, засновували нові, жертвували великі земельні наділи та надавали інші привілеї із ціллю розвитку регіонів, що відстають. Крім того, Католицька церква отримувала пожертви від всіх прошарків населення, що дозволило до кінця Середньовіччя зробити Церкву найбільшим власником земель і найбільшою економічною корпорацією в Європі» [13, с. 43].

Клюнійські реформи, на нашу думку, мали на меті вироблення основ загального християнського права, ідея якого була висунута ще в IX ст. Ліонським єпископом Агобардом: «Якщо Господь страждав, щоб усі ми примирились у його тілі <...>, то хіба цій божественній об'єднавчій справі не суперечить неймовірне розмаїття законів?» $[14$, c. 13].

На нашу думку, масштабність клюнійських реформ дає підстави говорити про вироблення специфічного клюнійського права, яке ґрунтувалось на синтезі церковних та канонічних норм, а також створювало умови для розвитку цивілі- зованих цивільно-правових відносин та міжнародного права. Саме клюнійське право лежало в основі папських реформацій. Незважаючи на те, що папські реформи не прийняли більшість європейських правителів і кліриків, клюнійські реформи дозволили папству стати наймогутнішою державною організацію середньовічної Європи [1, c. $233 ; 2$, с. 71].

Після Папської революції була створена нова система канонічного права, яка відділилась від богослужіння, риторики і моралі; у цій системі використовувались, з одного боку, знову відкрите римське право в аспекті мови і правової доктрини, з іншого - новий схоластичний метод під час зведення в єдине ціле суперечливих текстів $[12$, c. $50-51]$.

Отже, варто констатувати, що система церковного та канонічного права, яка сформувалась унаслідок церковної реформації, зокрема й не без участі клюнійців, а також низка різноманітних папських декреталій, які знайшли своє логічне вираження в постановах IV Лютеранського собору 1215 р., були свого роду транснаціональним зводом законів.

Крім того, нова правова система, яка утвердилась у всій Західній Європі, сприймалась як система, що безперервно розвивається, як динамічна. Точніше, західна правова свідомість у зв'язку із проголошеним правом для папи вводити нові закони, тобто здійснювати законотворчу діяльність, уперше сприйняла думку про те, що закон повинен постійно поповнюватись і оновлюватись. У 1234 р. з'явився перший офіційний звід канонів і декреталій, який підсумував і систематизував майже столітню працю; він слугував основним законом Римо-католицької церкви майже до 1917 р. [12, с. 51].

Багато із проведених Католицькою церквою реформ не можуть не викликати поваги і через 7 чи навіть 8 століть: уведення раціональної судової процедури замість містичних способів доведення - випробування вогнем і водою, поєдинків і ритуальних клятв; визнання взаємної згоди основою шлюбу, а злого умислу - основою злочину; розвиток принципу справедливості для захисту бідних і безправних перед багатими і тими, що мають владу, та посилення відповідальності за невиконання зобов'язань, заснованих на довірі та взаємній відповідальності, - ось далеко не повний перелік прикладів [12, с. 52-53].

Католицька церква створила першу сучасну правову систему, сучасне канонічне право, під широку юрисдикцію якого підпадали не тільки 
духовенство, але й миряни. Така система була необхідна для того, щоб «підтримувати цілісність кожного державного утворення, провести реформування кожного з них і зберегти рівновагу між усіма ними» [12, с. 269].

Висновки. Отже, Папська реформація Католицької церкви в добу Середньовіччя, проведена, серед іншого, завдяки участі клюнійських ченців, мала визначальний характер як для самої Католицької церкви, так і для всієї Європи загалом. Це був один із вирішальних чинників для розвитку церковного та канонічного права, яке остаточно сформувалось у XII-XIII ст. та відображало головні ідейні та політико-правові засади католицизму. Усе вищенаведене дозволяє говорити і про роль клюнійського кліру, а також про унікальне по своїй суті «клюнійське право».

\section{Література}

1. Забзалюк Д. Клюнійські реформи X-XI ст. та їх вплив на формування політико-правової доктрини католицької церкви. Науковий вісник Національної академії внутрішніх справ. Серія «Юридична». Київ, 2013. Вип. 4 (89). С. 229-235.

2. Забзалюк Д. Клюнійське право як головний чинник Папської реформації X-XI ст. Державотворення та правотворення в контексті євроінтеграції : матеріали доповідей, виступів і повідомлень учасників III-го Всеукраїнського круглого столу, м. Львів, 8 грудня 2017 р. Львів : ПП «Видавництво «БОНА»», 2017. 264 с. С. 69-72.

3. Религия и общество. Хрестоматия по социологии религии / под общ. ред. В. Гараджи. Москва : Наука, 1994. Ч. І. 300 с.

4. Заборов М. Папство и крестовые походы. Москва : Издательство АН СССР, 1960. 262 с.

5. Трубецкой Е. Религіозно-общественный идеалъ Западного христіанства в XI-мъ Въкъ. Идея божескаго царства въ творенняхъ Григорія VII-го и публи- цисттовъ - его современниковъ. Выпускъ І. Киевъ : Тип. С.В. Кульженко, 1897. 511 с.

6. Шейнман М. Папство. Москва : Изд-во АН CCCP, 1959. 216 c.

7. Заборов М. Крестовые походы. Москва : Издательство АН СССР, 1956. 277 с.

8. Петровъ М. Лекціи по всемірной исторіи. Санкт-Петербургъ, 1908. Т. II : История среднихъ въековъ. Ч. ІІ. 148 с.

9. Ле Гофф Ж. Рождение Европы. Пер. с фр. А. Поповой. Санкт-Петербург : Alexandria, 2007. 391 c.

10. Римській Папа и папы православной восточной церкви. Фрейбургъ въ Бризавъ. У книготорговца Б. Гердера, 1899. 138 с.

11. Всемирная история : в 10-ти т. / под ред. Е. Жукова. Москва : Гос. изд-во полит. Лит., 1957. Т. 3 / под ред. Н. Сидоровой. 895 с.

12. Берман Дж. Гарольд. Вера и закон: применение права и религии. Пер. с. англ. яз. Москва : Московская школа политических исследований, 2008. $464 \mathrm{c}$.

13. Ханс-Адам II, князь. Государство в третьем тысячелетии. Пер. с. англ. А. Мухаметшин. Москва : Инфотропик-Медиа, 2012. 320 с.

14. Bullough Donald. A. The Age of Charlemagne. London : Elek Books, 1965. 212 p.

15. Мулен Л. Повсякденне життя середньовічних ченців Західної Європи (X-XV ст.). Москва : Молода гвардія, 2002.

16. Джероза Ліберо. Церковне право. Пер. з нім. Н. Щиглевської. Львів : Свічадо, 2001. 336 с.

Забзалюк Д. $\epsilon .$, кандидат історичних наук, доцент, завідувач кафедри теорії та історії держави і права, конституційного та міжнародного права Львівського державного університету внутрішніх справ 